\title{
Histological features, starch accumulation and sprouting in the early root development of Jacaranda ulei (Bignoniaceae)
}

\author{
PAULO R.D. DA SILVA ${ }^{1}$ and VALDIR M. STEFENON ${ }^{1,2}$ \\ ${ }^{1}$ Núcleo de Cultura de Tecidos Vegetais, Centro Interdisciplinar de Pesquisas em Biotecnologia, \\ Universidade Federal do Pampa, Campus São Gabriel, Av. Antonio Trilha, 1847, 97300-000 São Gabriel, RS, Brasil \\ ${ }^{2}$ Programa de Pós-Graduação em Ciências Biológicas, Universidade Federal do Pampa, Campus São Gabriel, \\ Av. Antonio Trilha, 1847, 97300-000 São Gabriel, RS, Brasil
}

Manuscript received on August 2, 2012; accepted for publication on April 15, 2013

\begin{abstract}
The plant species occurring in the savanna region of the Cerrado biome in Brazil present typical morphological and physiological adaptations to a dry climate with seasonal occurrence of wildfires. In this study, the histological features of the root system, the main sites of synthesis and storage of starch and the initial phases of the bud development were characterized in Jacaranda ulei. The anatomical features observed in the root system of $J$. ulei are related to the needs of the species to survive in the Cerrado. The histochemical analyses demonstrated high synthesis of glucose and glycoprotein after the third day of in vitro culture, in the proximal cells of the cortical parenchyma of the exoderm. Meristematic primordia were observed in the ninth day and the beginning of the meristem formation was observed after 21 days of in vitro culture. Jacaranda ulei displays morphological, anatomical and storage features typical from resprouter species. However, it may be vulnerable to unsustainable exploitation. Considering the importance of this species for local people, more studies regarding its therapeutic properties should be performed, including the planning of appropriate programs for the species management and the production of selected clones through in vitro micropropagation.
\end{abstract}

Key words: Cerrado Biome, histology, savanna, wildfire.

\section{INTRODUCTION}

The Cerrado biome, in central Brazil, is the most species-rich tropical savanna of the world (Simon et al. 2009), housing about 4,400 endemic plant species (Myers et al. 2000) in an environment which ranges from open grasslands to dense woodlands (Hoffmann et al. 2004). The plant species occurring in the savanna regions of the Cerrado present typical morphological and physiological adaptations to a dry climate with

Correspondence to: Valdir Marcos Stefenon

E-mail: valdirstefenon@unipampa.edu.br seasonal occurrence of wildfires. Plant responses to fire have been examined extensively in different regions (Bell et al. 1996) and the species have been characterized as fire-sensitive (those killed by fire, called seeder species) or fire-tolerant (those surviving fire, called resprouter species), according to the capacity of regenerating after the burning events (Pate et al. 1991). Resprouter plants are capable to survive the complete removal of all the aerial parts by fire and to recover relatively quickly by growth of dormant buds protected from the 
action of fire either by thick bark or by location near the soil surface (Verdaguer and Ojeda 2002). Hence, root carbohydrate reserves are crucial for surviving in the savanna's environment, allowing the sprouting of new buds from the subterranean organs (Appezzato-da-Glória and Estelita 2000). Accordingly, high concentration of root total nonstructural carbohydrates is usually found in plant species growing in the savanna formations of the Cerrado biome (Hoffmann et al. 2004).

Many shrub and sub-shrub species of the Cerrado have already been studied at anatomical and histological level in order to understand the root features related to surviving in this environment, including species from the families Apocynaceae (Appezzato-da-Glória and Estelita 2000), Asteraceae (Vilhalva and Appezzato-daGlória 2006, Hayashi and Appezzato-da-Glória 2007, Appezzato-da-Glória and Cury 2011), Erythroxylaceae (Alonso and Machado 2007) and Bignoniaceae (Mauro et al. 2007).

Jacaranda ulei Bureau \& K. Schum. is an evergreen shrub of the Bignoniaceae family, native to the savanna formations of the Cerrado. This species has an underground system largely employed in the folk medicine for the treatment of diseases as rheumatism, backache, skin disorders, urinary tract diseases and amoebic dysentery (Barros 1987, Neto and Morais 2003). Despite its ecological and therapeutic importance, no studies on the underground system of this species have been developed up to now. In this study, we describe the histological features of the root system and characterize the main sites of synthesis and storage of starch and the initial phases of the bud development in Jacaranda ulei in in vitro conditions, in order to achieve new information on the biology of this species.

\section{MATERIALS AND METHODS}

Mature capsules were collected from 12 donor plants of Jacaranda ulei (five capsules/plant) growing in natural populations in an area of Cerrado in the vicinity of Brasília, DF, Brazil (1545'S, $\left.47^{\circ} 54^{\prime} \mathrm{W}\right)$. Seeds were randomly sampled, surfacesterilized with ethanol and sodium hypochlorite and 30 healthy seeds were selected and inoculated for germination in test-tubes $(25 \mathrm{~mm} \times 150 \mathrm{~mm})$ containing $25 \mathrm{~mL}$ of a culture medium composed by $6.0 \mathrm{~g}$ of agar in $1,000 \mathrm{~mL}$ of water. The testtubes were closed with aluminum caps, sealed with plastic film and maintained during 30 days in culture room at $25 \pm 2^{\circ} \mathrm{C}, 16 \mathrm{~h}$ photoperiod and light intensity of $40-50 \mu \mathrm{mol} \cdot \mathrm{m}^{-2} \cdot \mathrm{s}^{-1}$ provided by coolwhite Sylvania ${ }^{\circledR}$ fluorescent lamps.

For the establishment of the in vitro culture, three explants $(1.0 \pm 0.3 \mathrm{~cm}$ long) were excised from the main root of each plantlet and inoculated into culture tubes containing $1 / 4 \mathrm{MS}$ basal medium (Murashige and Skoog 1962) pH 5.6, supplemented with 44.4 $\mu \mathrm{M}$ of 6-benzil-aminopurine and $49.2 \mu \mathrm{M}$ of indole3-butyric acid. Sucrose $\left(20 \mathrm{~g} \cdot \mathrm{L}^{-1}\right)$ and myo-inositol $\left(100 \mathrm{mg} \cdot \mathrm{L}^{-1}\right)$ were added to the medium and it was solidified with $6 \mathrm{~g} \cdot \mathrm{L}^{-1}$ of agar. The cultures were kept at $25 \pm 2{ }^{\circ} \mathrm{C}, 16 \mathrm{~h}$ photoperiod with an irradiance of $40-50 \mathrm{~mol} \cdot \mathrm{m}^{-2} \cdot \mathrm{s}^{-1}$ during 30 days.

For the histological analyses, three plantlets were randomly sampled in days $0,3,6,9,21$ and 30 of culture, the root system excised and transferred to a solution of formaldehyde:acetic acid:ethanol $70^{\circ}(1: 1: 8, \mathrm{v} / \mathrm{v} / \mathrm{v})$ during 24 hours, for fixation of the tissues. The samples were then dehydrated in a graded alcohol series (10-96\%) during $30 \mathrm{~min}$ at each step. The samples were embedded in Technovit $7100^{\circledR}$ resin and alcohol $(1: 1, \mathrm{v} / \mathrm{v})$ during $48 \mathrm{~h}$, and then with benzoyl peroxide $0.1 \mathrm{~g} \cdot \mathrm{mL}^{-1}+$ Technovit $7100^{\circledR}$ resin for $48 \mathrm{~h}$. Samples were polymerized with dimethyl-sulfoxide and maintained at $60^{\circ} \mathrm{C}$ during $24 \mathrm{~h}$. In addition to the resin preparation, samples were also diaphanized with xylene and filled with paraffin. For both preparations, sections $(10 \mu \mathrm{m})$ were obtained using a rotary microtome, mounted on slides with a drop of water for resin or with Haupt's adhesive for paraffin and stained with 
$0.0125 \%$ basic fuchsin and $1.0 \%$ toluidine blue $\mathrm{O}$. For the identification of the sites of synthesis and storage of starch, the samples were stained with lugol solution. Relevant aspects were identified and photographed using a digital camera coupled to a Bioval ${ }^{\circledR}$ L2000C light microscope.

\section{RESULTS AND DISCUSSION}

In this study, in vitro regenerated plantlets of $J$. ulei were employed for the study of the morphological and histochemical features of the species root development. The use of 6-benzil-aminopurine and indole-3-butyric acid in the $1 / 4 \mathrm{MS}$ basal medium allowed successful development of the root explants and can be considered a promising alternative for in vitro culture of $J$. ulei.

The histological analysis of the Jacaranda ulei roots in transversal section revealed a multiseriate epidermis and a uniseriate exodermis. The cortical parenchyma is composed by eight to ten isodiametric cells with thin walls, from the first to the fifth layers. From the sixth to the most internal layer the cortical cells are hypertrophied and many intercellular spaces are observed. The endodermis is uniseriate and the vascular cylinder concerns a uniseriate pericycle with small cells in comparison to the hypertrophied cortical cells (Figure 1A).

These anatomical features observed in the root system of $J$. ulei are related to the needs of the species to survive in the dry climate of the Cerrado, in which the occurrence of wildfires is recurrent. The capacity of a plant to live on in such an environment is associated to its ability to survive the fire itself and the post-fire conditions, through anatomical and physiological adaptations. Multiseriate epidermis, uniseriate exodermis and two cell types in the cortical parenchyma are characteristics which aid the wildfire survival and the root sprouting in the rainy season. Resprouting is a common plant response to injury from a variety of insults, including drought and fire (Bradshaw et al. 2011) being, therefore, vital in plants of the Cerrado.
In the in vitro cultured root explants, high synthesis of glucose and glycoprotein was observed after the third day, in the proximal cells of the cortical parenchyma of the exoderm (Figure 1B), revealing the main point of glucose synthesis. Also in the cells subjacent to the exoderm, a high synthesis of glucose and accumulation of starch were evidenced in the third day of culture, mainly in the two initial layers of parenchymatic isodiametric cells of the cortex (Figure 1B). In the sixth day, lysis of starch was observed in the cells from two layers of the cortex and many amyloplasts were found within the small parenchymatic cells close to the hypertrophied cells (Figure 1C). In the ninth day, the starch was concentrated in the cortex, rounding the dividing hypertrophied cells of the cortical parenchyma (Figure 1D), revealing the initial formation of buds. The buds were clearly visualized after 21 days of culture (Figure 2A-B) and the beginning of the sprouting (direct organogenesis) was observed after 30 days (Figure $2 \mathrm{C}-\mathrm{D}$ ).

The presence of carbohydrate in the cortical parenchyma of other Cerrado species has been reported (Hayashi and Appezzato-da-Glória 2007, Appezzato-da-Glória and Cury 2011), evidencing the importance of this reserve of nutrients for savanna plants. Bell et al. (1996) presented clear evidence that certain features of the morphology, anatomy and nonstructural carbohydrates storage displayed by southwest Australian representatives of the Epacridaceae are preferentially correlated with fire response strategy from either the seeder species (those succumbing to fire) or resprouter species (those capable of surviving fire). Concerning nonstructural carbohydrates storage aspects, resprouter species present higher root starch values than seeders (Bell et al.1996), as reported by Hoffmann et al. (2004) for J. ulei, in comparison with the forest species $J$. puberbula.

The accumulation of nonstructural carbohydrates in the roots of $J$. ulei is associated with the requirement of reserves in order to survive the dry season and 


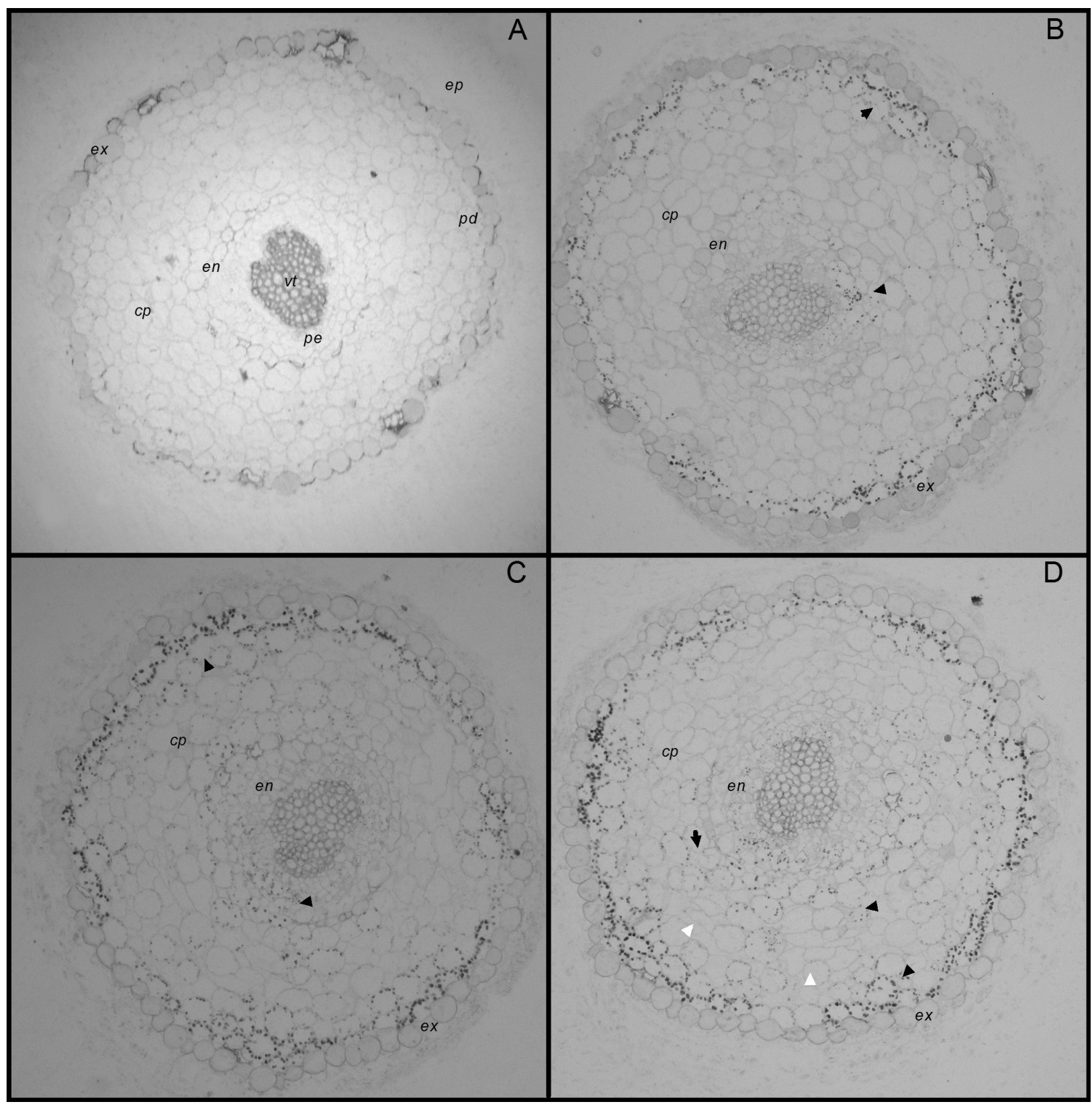

Fig. 1 - Light micrographs of transversal sections of the root system of $J$. ulei stained with lugol. A: at day zero, without visual accumulation of starch reserves. The epidermis $(e p)$, exodermis $(e x)$, peridermis $(p d)$, cortical parenchyma ( $c p)$, endodermis $(e n)$, pericycle (pe) and the vascular tissue ( $v t)$ are evidenced. B-D: after 3 days (B), 6 days (C) and 9 days (D) of culture. Black arrowheads determine the accumulation of starch reserves in the exodermis (ex), in the pericycle (pe) around the vascular tissue $(v t)$ and in the cortical parenchyma $(c p)$. White arrowheads indicate dividing cortical cells rounded by starch. These dividing cells will give rise to buds.

to resprout during the rainy season. The initial development of buds in the underground system of $J$. ulei was characterized after the ninth day, evidenced by the buds observed in the hypertrophied cells of the cortical parenchyma. The starch, the main source of energy of this process, is synthesized in the proximal cells of the cortical parenchyma of the exoderm and transported to the cortical parenchyma, around these 


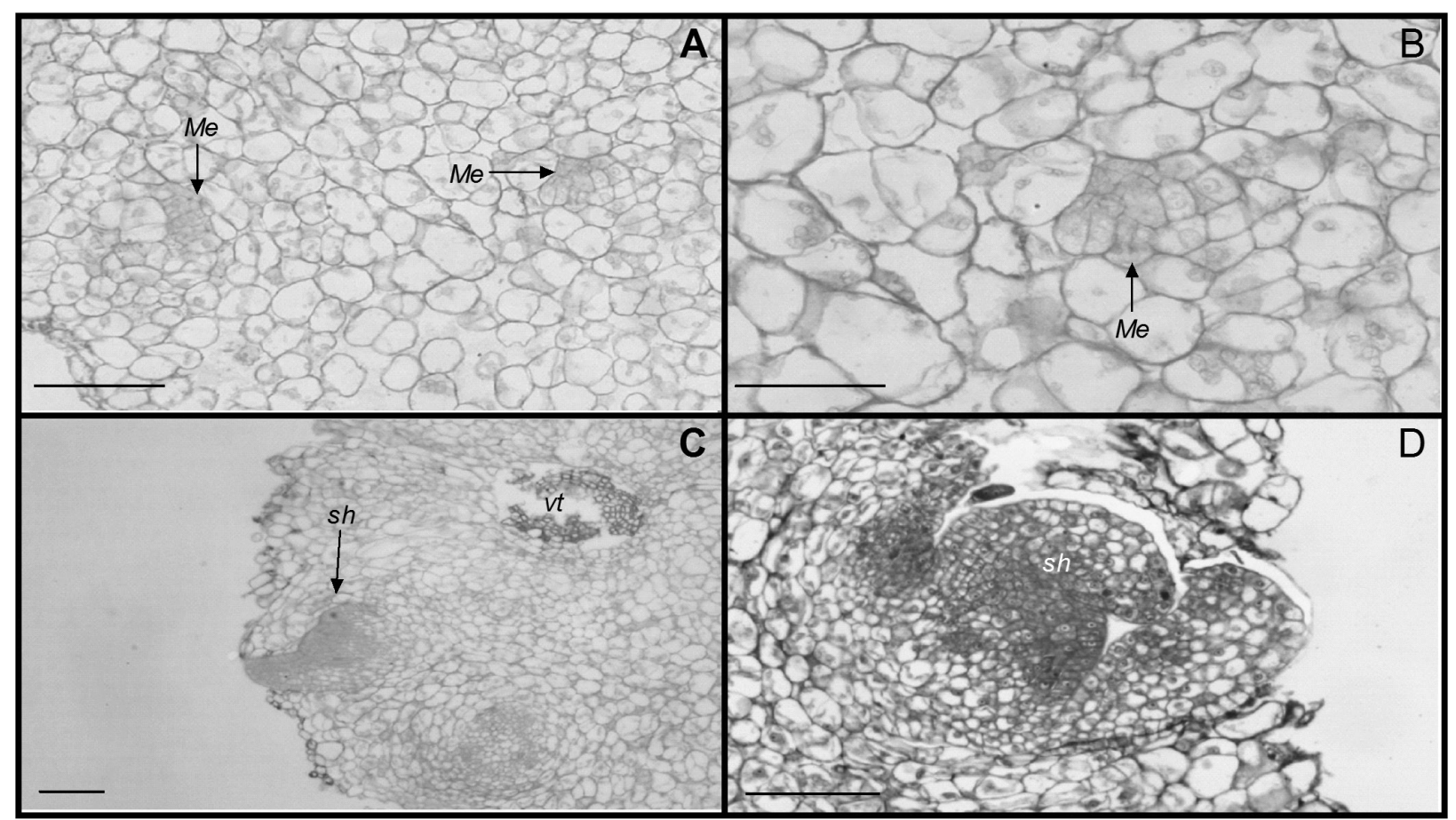

Fig. 2 - Light micrographs of transversal sections of the root system of J. ulei. Regeneration of meristems (Me) in the cortical parenchyma (A and B) after 21 days of culture and the shoots $(s p)$ after 30 days of culture $(\mathrm{C}$ and $\mathrm{D})$. The collapsed vascular tissue $(v t)$ can be observed in C. Scale bars: $50 \mu \mathrm{m}(\mathrm{B}) ; 100 \mu \mathrm{m}$ (A, C and D).

bud cells. Starch grains in the plastids of bud dividing cells and the conversion of starch into glucoses during bud development have been considered a common aspect of organogenesis, associated with the nutritional requirements of the cells (Arnold 1987, Appezzatoda-Glória and Machado 2004). In addition, such reserve of nonstructural carbohydrates enables the development of new shoots when the aerial parts are damaged by fire or drought. The development of aerial shoots from buds located in underground structures associated to the accumulation of carbohydrates have been referred to emphasize the importance of bud-bearing structures in the savanna formations of the Brazilian Cerrado, since they contain the buds and reserve substances needed for plant regeneration (Appezzato-da-Glória and Cury 2011).

Plant species living in environments with seasonal occurrence of wildfires display different strategies for species persistence after fire, mainly regenerating by seeds even after being killed by the fire or regenerating by resprouting and reproducing by means of seeds or by any range of vegetative means (Bell et al. 1996). This study presents evidences that $J$. ulei displays some morphological, anatomical and storage features typical from resprouter species. However, even having the main characteristics needed to survive the drought and the wildfires in the Cerrado, it may be vulnerable to unsustainable exploitation. Thus, considering the ecological and medicinal importance of this species for local people, more studies regarding the therapeutic properties of $J$. ulei should be performed, including the planning of appropriate programs for the species management and the production of selected clones employing in vitro micropropagation techniques.

\section{ACKNOWLEDGMENTS}

The authors thank Dr. Claudio Vicinius de Senna Gastal Jr. (in memoriam) by helping in the initial experiments, Conselho Nacional de 
Desenvolvimento Científico e Tecnológico (CNPq) (Process 314664/2009-2) and UNIPAMPA by financial support and grants.

\section{RESUMO}

As espécies de plantas ocorrendo na região de savana do Bioma Cerrado no Brasil apresentam adaptações morfológicas e fisiológicas típicas para um clima seco com ocorrência sazonal de incêndios. Neste estudo, as características histológicas do sistema radicular, os principais pontos de síntese e acúmulo de amido e as fases iniciais do desenvolvimento de gemas foram caracterizados em Jacaranda ulei. As características anatômicas observadas no sistema radicular de $J$. ulei estão relacionadas com as necessidades da espécie para sobreviver no Cerrado. As análises histoquímicas demonstraram alta síntese de glucose e glicoproteínas após o terceiro dia de cultura in vitro, nas células proximais do parênquima cortical da exoderme. Primórdios de meristemas foram observados no nono dia e o início da formação de meristemas foi obervado após 21 dias do cultivo in vitro. Jacaranda ulei apresenta características morfológicas, anatômicas e de estocagem típicas de espécies com rebrotação. Contudo, ela pode estar vulnerável à exploração não-sustentável. Considerando a importância desta espécie para as comunidades locais, mais estudos sobre suas propriedades terapêuticas devem ser realizados, incluindo o planejamento de programas apropriados para o manejo da espécie e a produção de clones selecionados através de micropropagação in vitro.

Palavras-chave: Bioma cerrado, histologia, savana, fogo.

\section{REFERENCES}

Alonso AA AND Machado SR. 2007. Morphological and developmental investigations of the underground system of Erythroxylum species from Brazilian cerrado. Aust J Bot 55: 749-758.

APPEZZATO-DA-GLÓRIA B AND CURY G. 2011. Morphoanatomical features of underground systems in six Asteraceae species from the Brazilian Cerrado. An Acad Bras Cienc 83: 981-991.

APPEZZATO-DA-GLÓRIA B AND EsTELITA MEM. 2000. The developmental anatomy of the subterranean system in Mandevilla illustris (Vell.) Woodson and M. velutina (Mart. ex Stadelm.) Woodson (Apocynaceae). Rev Brasil Bot 23: 27-35.
APPEZZATO-DA-GLÓRIA B AND MACHADO SR. 2004. Ultrastructural analysis of in vitro direct and inderect organogenesis. Rev Brasil Bot 27: 429-437.

ARNOLD SV. 1987. Effect of sucrose on starch accumulation in and adventitious bud formation on embryos of Picea abies. Ann Bot 59:15-22.

BARROS MAG. 1987. Plantas medicinais - usos e tradições em Brasília - DF. Oreades (UFMG) 8: 140-151.

Bell TL, Pate JS AND DiXON WD. 1996. Relationships Between Fire Response, Morphology, Root Anatomy and Starch Distribution in South-west Australian Epacridaceae. Ann Bot 77: 357-364.

BRADSHAW SD, DiXON KW, HOPPER SD, LAMBERS H AND TURNER SR. 2011. Little evidence for fire-adapted plant traits in Mediterranean climate regions. Trends Plant Sci 16: 69-76.

HAYASHI AH AND APPEZZATO-DA-GLÓRIA B. 2007. Anatomy of the Underground System in Vernonia grandiflora Less. and $V$. brevifolia Less. (Asteraceae). Braz Arch Biol Tech 50: 979-988.

HOFFMANN WA, ORTHEN B AND FrANCO AC. 2004. Constraints to seedling success of savanna and forest trees across the savanna-forest boundary. Oecologia 140: 252-260.

Mauro C, Pereira AMS, Silva CP, Missima J, OhNuki T AND TINALDI RB. 2007. Estudo anatômico das espécies de cerrado Anemopaegma arvense (Vell.) Stellf. ex de Souza (catuaba), Zeyheria montana Mart. (bolsade-pastor) e Jacaranda decurrens Chamisso (caroba) - Bignoniaceae. Rev Bras Farmacog 17: 262-265.

Murashige T And SKoog F. 1962. A revised medium for rapid growth and bioassays with tobacco tissue culture. Phys Plant 15: 473- 497.

Myers N, MitTermeier RA, MitTermeier CG, FonsecA GAB AND KENT J. 2000. Biodiversity hotspots for conservation priorities. Nature 403: 853-858.

Neto GG AND MoRAIS RG. 2003. Recursos medicinais de espécies do Cerrado de Mato Grosso: um estudo bibliográfico. Acta Bot Bras 17: 561-584.

PATE JS, MENEY KA AND DiXON KW. 1991. Contrasting growth and morphological characteristics of fire-sensitive (obligate seeder) and fire-resistant (resprouter) species of Restionaceae (S. Hemisphere restiads) from southwestern western Australia. Aust J Bot 39: 505-525.

Simon MF, Grether R, QueIroz LP, SKema C, PenNington RT AND HuGHES CE. 2009. Recent assembly of the Cerrado, a neotropical plant diversity hotspot, by in situ evolution of adaptations to fire. Proc Nat Acad Sc USA 106: 20359-20364.

VERDAGUER D AND OJEDA F. 2002. Root starch storage and allocation patterns in seeder and sprouter seedlings of two Cape Erica (Ericaceae) species. Am J Bot 89: 1189-1196.

VILHALVA DAA AND APPEZZATO-DA-GLÓRIA B. 2006 Morfoanatomia da raiz tuberosa de Vernonia oxylepis Sch. Bip. in Mart. ex Baker - Asteraceae. Acta Bot Bras 20: 591-598. 